\title{
Exploration of the educational function in Independent College teachers' teaching process
}

\author{
Zhang Zhong \\ Guangzhou College of South China University of \\ Technology \\ Guangzhou, China \\ e-mail: zhangzhong@gcu.edu.cn
}

\author{
Li Weihua \\ Guangzhou College of South China University of \\ Technology \\ Guangzhou, China \\ e-mail: liwh@gcu.edu.cn
}

\begin{abstract}
In recent years, the Independent College as a new force in the higher education system. In the popularization of higher education trends, people's awareness of the era of the knowledge economy and the penetration of the market mechanism in higher education, The Independent Colleges had a rapid development. But many problems were exposed under the rapid expansion of the enrollment scale, such as contradiction of school conditions and its enrollment, how to make the teachers structure rational, those problems widespread concern caused by the higher education sector and society, how to achieve educating people has become a top priority issue in the teaching process.
\end{abstract}

Keywords- enrollment; teaching staff; educating people; Independent College

\section{ANALYSIS OF THE PROBLEMS AND CAUSES IN}

\section{INDEPENDENT COLLEGE TEACHERS’ TEACHING PROCESS}

Teaching and educating, serve as role models, these are the most sacred and most fundamental duty of teachers, but also the core of the professional ethics of teachers. However, some teachers had a lack of correct understanding, teaching and educating people are separated, and only focus on teaching expertise, regardless of the students' ideological and political performance, they focus on student test scores, regardless of the overall quality of students; some teachers simply to complete the task of teaching responsibility, they can't take the initiative to understand students and care about the students grow, lack of exchange and communication between students; some teachers role models weak awareness, lack of self-esteem, self-respect, self-love spirit, difficult to play an exemplary role; some teachers free and easy, late arrival, instrument, not the vulgar manners; some teachers accept students banquets and valuable gifts, when the exam send "feelings points", "gift points"; some teachers scholars scorn each other, intentionally or unintentionally discount other teachers in front of the students; there are teachers to use class vent to social discontent, and do not pay attention to own words and deeds to student's influence and so on. To sum up the reasons of the problems are mainly as follows:

\section{A. Lack of teaching experience, without the ability to control the classroom}

The independent college full-time young teachers are undergraduate students or graduate students, they assume a variety of teaching task just graduated. They don't go through the adaptation and buffer stage, then direct mount guard, the teaching quality are affected in great degree. Independent college young teachers lack teaching experience not only displays in the teaching skills, teaching methods, Is short of, more important is too theory and empty in classes, lack of professional practice experience to support and complement the theory, leading to the effect is not good in classroom teaching. More energy can't be devoted on education due to no good control of the teaching content, it lead to the separation of teaching and educating people.

\section{B. Lack of professionalism and sense of responsibility should improve}

Part of the independent college young teachers didn't put himself as an "engineers of human souls", also didn't have the education work as "the most glorious career under the sun" to inherit culture knowledge, spread scientific truth, shape good heart, but their own engaged in the work as a means of livelihood. Because of this, some teachers sink to them, and just have no intention to exploration and research on educational ideas, teaching content, teaching forms and methods, there is a refusal to change, to make progress; some teachers half - hearted about the work, inadequate lesson planning, just echoes what the book says, job correcting not seriously, lack of tutoring after class, only focus on the number of lessons, do not pay attention to the quality of teaching, leading to dissatisfaction of students. In addition to teaching outside of work, some of the young teachers mutual shirk things which nothing to do with them, do not want to do things which no good to themselves, those things caused a greater negative impact on the management of the entire teaching team, This led to the personal growth of young teachers adverse finally.

\section{The working pressure is too large, lack of management experience}

The independent college teachers is mainly composed of 30-year-old young teachers, a few years of teaching experience of young teachers to become the backbone teachers. They bear the professional teaching tasks, at the same time they also bear the part of the teaching management work. And these backbone teachers lack of experience in the teaching management, it will cause part of the young teacher branch and contradictions, which seriously influence the teaching order and the quality of teaching. So 
to undertake this work for young backbone teachers still need time to understand and comprehend the management, but independent college realistic teaching environment can't have too much time to learn for these young teachers, so they have a lot of pressure, it will affect the whole teaching process.

\section{The utility thought seriously, no good team work spirit}

Minority teachers can't properly handle the relationship between "moral" and "benefit", the outlook on life and the values have deviation, the ethics of love education, dedicated to education damped down, hard work and the spirit of selfless devotion decline, even to the utilitarian principle to treat their career and work. Some teachers yield to the temptation of economic interest, compete for fame, unscrupulous, accept the school for the job is not to need as the principle, but as to whether the advantage for the principle; some teachers do not feel at ease teaching work, in the ever-changing market and colorful world, could not stand lonely, can't stand poor life, through the various ways use their knowledge and skills to participate in "market competition"; some teachers for the pursuit of personal interests, use the school culture than get capital, regardless of the school and students, always leave the post without permission; Part of the teachers lack the spirit of unity, cooperation, respect for personal struggle, only focused on the achievement of self-worth, colleagues don't respect each other, don't complement each other and don't active cooperation, but mutual scandals and counteract each other's efforts, it is difficult to form an effective education force.

\section{INDEPENDENT COLLEGE STUDENTS'}

CHARACTERISTICS AND AN OVERVIEW OF THE TEACHING PROCESS EDUCATION CONNOTATION

\section{A. The distinctive characteristics of independent college students}

Most of independent college students are healthy, positive and upward students, but they have characteristic of poorly prepared, strong self-esteem, poor self-control and binding, positive cultural and sports activities, good sense on practical innovation, poor collective conception, strong desire of self-expression, poor self-care ability, good family economic condition, strong psychological dependence, and too prominent personality. To the face of the independent college students' characteristics, traditional education management models and methods have been unable to meet the requirement of the new situation, unable to give full play to the students initiative, unable to better guide students selfeducation, self-management and self-service, it causes the student numbness and indifference to the school education management.

\section{B. An overview of the teaching process education connotation}

August 31, 2007, CHINA’S President Hu Jintao comrade in the "national outstanding teachers' representative symposium speech" clearly pointed out: must adhere to the people-oriented education, moral education first, it was the fundamental education responsibility, strengthen patriotism education, further carry out the ideal faith education, strengthening and improving students' ideological and political work, integrate the socialist core value system into the china's education system, guide students to build up the correct world outlook, values, honor or dishonor view, and efforts to train those students who have combined development in moral, intellectual and physical education, make them become a socialist builders and successors.

Teaching process is the most suitable link for education, classroom teaching is not just the spread of knowledge, need more comprehensive education, make the students as the main body of the activities, mobilize the initiative and interesting in learning, and make them happy to learn, love of learning, able to learn, make more enjoyable in learning; foster student's volitional quality, coordination ability, habits, skills and so on. This requires that teachers have to consciously realize through each lesson, penetrate in the whole process of classroom teaching, the teaching of this kind can reflect the essence of education.

The intercourse between teachers and students is most purposeful and planning strongest in the teaching activities. Classroom teaching is a sacred and full of energy teaching, it is a holistic and dynamic process of interaction between teachers and students, this is also a part of the life activities. In the use of the books has a strong education in the teaching activities, which makes the teaching is full of educational. If the teacher really understand and carry out every subject and every lesson instructional objectives, it will enable students to form correct understanding of society, understanding natural ability and form the good scientific quality. At the same time, the teachers rigorous train students through the teaching process, it make students have assiduous spirit and a strong will. Regularity and rigor of subject knowledge, learning atmosphere, are recessive education factors. Teachers should be approached students, understand and love students, protect the interesting, seize the opportunity then galvanize the students. To education fused into the teaching activity, to education fused into the impart knowledge, to education fused into the teachers statements and actions, than the education can fused into the each class teaching process.

\section{MEASURES TO REALIZE THE EDUCATIONAL} FUNCTION IN INDEPENDENT COLLEGE TEACHERS' TEACHING PROCESS

\section{A. Strengthening teachers' ideological quality education}

The connotation of ideological quality in the broader, it includes a teacher thought morality, self-cultivation, work enthusiasm, political views, education concepts, reform consciousness and so on. Strengthen their education and accept education of consciousness, study hard, progressively improved, constant absorbing new knowledge, so as to help strengthen and improve their ideological quality. A university teacher must pay attention to the development of educational work, should continuously to study in the professional teaching, do the best to make a lot of 
achievements the innovation and the hard work, with an open mind to learn, improve weakness and further develop strengths, always love your job. The university teachers should have strong sense of responsibility, everywhere to improve teaching in the first place and the teaching accident should be seen as unforgivable mistake. The professional teacher should guide students by the good image at any time, both must be strict with students, and kindness get along with students, respect students, concerned about their study and life, do our best to help students solve difficulties. Therefore, we should strengthen the teachers' ideological quality education, strengthen the evaluation supervision, perfect teachers' ideological quality incentive mechanism, vigorously promote advanced models, give full play to models exemplary role.

\section{B. Ascension teacher's personal charisma}

Young college students' personality is not stable, have highly malleable, they are susceptible to the influence of environment and education, it is easy to respect and love their favorite teachers. Teachers' personal culture in a certain extent determines whether he can get their respect and affection. Teachers in universities should have both political integrity and ability, very decent images, elegant behavior, elegant and witty discourse, rigorous and thoughtful selfdiscipline, teachers exercise an invisible, formative influence on the pupils' character by the noble sentiment and character, edify the students with versatile abilities, attract students with rich knowledge, educate students with farsightedness vision, so this teacher can win the respect of students, than the students will very interest in its teaching course. At the same time, outstanding teacher's personality have a guided exemplary role for forming students character, those teachers will be an example of the students, can stimulate the students positive spark which buried in the bottom of their heart, can achieve their full potential, and become a useful talents for society.

\section{Strengthening respect for the dignity in the teaching process}

In the field of education "people-oriented", is take the student as this, all education must be based on students' development as the starting point and destination point, to hold the idea of "people-oriented" implemented in education, the teacher must fully respect each student's personality. The idea of "Education service" explain that education is service, the student is education service object, the school is for student services, and finally the high quality service will be provided to students by teachers, and formed a "one central task, two basic points", it explain that "to taking the student as the central task, to teaching and education as two basic points". "Education services" to be practicable, it change over the subject and object in the education process, turn the subject into learning guidance, courseware designers, teaching presenter, emotional communication coordinator and career planning referee in the traditional teaching process. Teachers' all activities must be around the center is the student's comprehensive development.

\section{Strengthening educate, enable teachers to keep lasting love his subject}

Teachers love their profession, love the course that they taught, this way, they will offer to teach and educate, control class reasonably; they will master the teaching content; they will invest more energy in selecting proper teaching method, make the classroom full of zest. The ideal teaching class, teachers and students can produce depth interaction. The depth of interaction, first requests the teacher to grasp the nature of the course, make the class becomes a free, open, mind and intelligence exchange activities; second, teachers should pay attention to knowledge innovation, pay more attention to combine the impart knowledge with the conduct oneself and business closely. Teachers keep lasting love his subject is necessary condition for reasonable education in teaching process.

\section{E. Strengthen learning and innovation, and constantly study professional knowledge}

The teacher must have a consummate professional quality. As one of the best teachers in College, should have profound professional knowledge and keep abreast of the subject and related disciplines new development, update and improve our knowledge structure. Therefore, college teachers must be willing to study business, take up readily with new ideas, absorb the new knowledge, dare to explore the frontiers. On the Basis of accurate understanding teaching materials, the lecture should be taught depth and can explain profound theories in simple language, so that students are easy to accept, and teaching effect will be enhanced. Pay attention to scientific research, strengthen the sense of pioneering and innovative spirit, to explore actively in the education practice, to enhance learning and innovation, good use of creative thinking. Teachers must have excellent teaching art, can do a heuristic lecture and active class discussion, than students will have their whole heart into class, such can achieve the effect of imparting knowledge and educating people.

\section{F. Teaching habit will be strengthened to improve a good educational environment}

Sincere emotion produced in real life, the interpersonal relation from group living play an important role for the formation of educational environment from the modern psychology. Therefore, need to build industry and homespun school culture, advocate love, dedication, inquiry, cooperation teaching style, help teachers form a correct outlook on life, world outlook, values. Those teacher who love students, dedicate themselves to teaching, have exquisite expertise, should be praised and rewarded in school activities of moral education. Their exquisite expertise, good moral and culture should be magnified, than they become a good example. It will enhance all the teachers' dedication to work and the sense of responsibility, and form a good education environment. 


\section{CONCLUSION}

University education, teaching is the means, education is fundamental. "Teaching" and "education" want two tactics to catch, two tactics wants hard. Therefore, teachers finish the teaching at the same time should improve their awareness of education, consciously explore regularity of education, do our best teach not only knowledge but life. I believe that as long as each teacher can give students as her children, the educational effect will be continue to improved, can make the students will become talent who country need. Finally, I sincerely hope that this paper can throw away a brick in order to get ages in the process of university teaching and education, especially in independent college.

\section{REFERENCES}

[1] Xinhua News Agency, CHINA'S President Hu Jintao comrade in the national outstanding teachers' representative symposium speech [J], China's Higher Education, 2007, 18(9), pp.1-2.

[2] Lu Genshu, Peng Zhengxia, Fostering Harmonious Academic Ecology in Universities and Promoting the Growth of Innovative Talents in Basic Research [J], Research in Higher Education of Engineering, 2011(1), pp.60-66.

[3] Zeng Jiyun, Differentiated Development Instruction research [M], Bengjing: Capital Normal University Press, 2006, 9.

[4] He Lingxiao, On the study-atmosphere building of subordinate colleges [J], Journal of Jiangsu University (Higher Education Study Edition), 2006, 28 (1), pp.39-42.
[5] Ban Hua. Moral Education Idea and It's Reform-The Trend of Hunanistic Moral Education in the New Century [J]. Journal of Nanjing Normal University (Social Science Edition), 2002(04), pp.73-80.

[6] Ban Hua, Xue Xiaoyang, Theoretical Character of Research on Models of Moral Education in China [J], Peking University Education Review, 2004(01), pp.71-76.

[7] Feng Wenquan, Reconsideration about the Innate Character of Moral Education: A Multi-disciplinary Perspective [J], Educational Research, 2005(10), pp.11-17.

[8] Tan Chuanbao, On the Model of Moral Education through Appreciation [J], Journal of Beijing Normal University (Social Science Edition), 2002(02), pp.107-112.

[9] Ji Aimin, Moral Education Model in China: Summary and Trends [J], Wuhan University Journal (Humanity Sciences), 2006(01), pp.120124.

[10] Yi Lianyun, Deng Da, Knowledge Foundation of School Moral Education and Moral Education Curriculum Reform [J], Educational Research, 2007(02), pp.17-21.

[11] Long Xianzhong, Zhong Heping, The Annotation and Construction of Dialogue Moral Education in Higher Education Institutions from the Perspective of Humane Care [J], Journal of Higher Education, 2012(01), pp.86-90.

[12] Liu Enyun, Life Education: lack and Remedies of Moral Education in Universities [J], Journal of Shandong Normal University (Humanities and Social Sciences), 2011(03), pp.102-105. 